ఠ

\title{
From 3D spheroids to tumor bearing mice: efficacy and distribution studies of trastuzumab-docetaxel immunoliposome in breast cancer [Erratum]
}

Rodallec A, Sicard G, Giacometti S, et al. Int JNano. 2018;13: $\quad$ On page 6684, Table 1 should be as follows: $6677-6688$.

Table I

\begin{tabular}{|l|l|l|}
\hline Treatment & Beginning of treatment $\left(\times 10^{10}\right)$ & End of treatment $\left(\times 10^{10}\right)$ \\
\hline MDA-MB-453 bearing mice & 1.15 & 1.73 \\
\hline Control & 0.877 & 2.53 \\
\hline Liposome + free trastuzumab & 1.70 & 1.72 \\
\hline Immunoliposome & \multicolumn{2}{|l|}{} \\
\hline MDA-MB-23I bearing mice & 1.19 & 5.96 \\
\hline Control & 1.49 & 3.88 \\
\hline Liposome + free trastuzumab & 1.38 & 3.44 \\
\hline Immunoliposome & & \multicolumn{2}{|l|}{} \\
\hline
\end{tabular}

International Journal of Nanomedicine

\section{Publish your work in this journal}

The International Journal of Nanomedicine is an international, peerreviewed journal focusing on the application of nanotechnology in diagnostics, therapeutics, and drug delivery systems throughou the biomedical field. This journal is indexed on PubMed Central, MedLine, CAS, SciSearch ${ }^{\circledR}$, Current Contents ${ }^{\circledR} /$ Clinical Medicine,
Journal Citation Reports/Science Edition, EMBase, Scopus and the Elsevier Bibliographic databases. The manuscript management system is completely online and includes a very quick and fair peer-review system, which is all easy to use. Visit http://www.dovepress.com/ testimonials.php to read real quotes from published authors. 